\title{
Phenol Transport and Biodegradation Model in an Unsaturated Porous Media from Wastewater Discharge
}

\author{
Naresh K. Sharma, Berlin M.
}

\begin{abstract}
To minimize groundwater pollution and suggest appropriate remedial actions, sound numerical models must be developed to predict the fate, transport and biodegradation of pollutants in partially treated or untreated industrial wastewater. Phenol is an aromatic organic compound produced on a large scale and is also released as major organic pollutant from several industrial wastewater (pharmaceutical, petroleum, coal refineries etc.,). Biodegradation of phenol in soil is generally rapid especially in presence of nutrients and acclimated microbes which are discharged along with the partially treated wastewater. A numerical model has been developed to predict the fate of phenol from industrial wastewater discharged on to a porous unsaturated soil media. The transport processes of advection, dispersion, and biodegradation process using Haldane growth and inhibition have been incorporated in the numerical model. The results suggest that acclimated microbes in the wastewater has a potential to degrade phenol up to $1500 \mathrm{mg} / \mathrm{L}$ at a bacterial concentration of $0.1 \mathrm{mg} / \mathrm{L}$ and soil depth of $50 \mathrm{~cm}$. The results also show that phenols desorb at a depth of $100 \mathrm{~cm}$ from $12^{\text {th }}$ day and are simultaneously acted upon by the increased microbial concentration. In essence, high microbial concentration significantly decreases the phenol movement in the unsaturated zone, particularly at a larger depth and at higher time levels which eventually affects the groundwater quality.
\end{abstract}

Keywords: Phenol, Transport model, Biodegradation model, Wastewater discharge, Haldane Kinetics.

\section{INTRODUCTION}

$\mathrm{Co}$ ontinuous or intermittent release of partially treated or untreated wastewater from several industries could lead to accumulation of several organic and toxic compounds in soils, which eventually will leach through soil to accumulate

in groundwater. Presence of significant concentrations of phenol in groundwater mainly near or at hazardous waste sites have been reported (ATSDR, 2008). United States

Environmental Protection Agency (USEPA) has enlisted phenols and their derivatives as priority pollutants and therefore the treatment and safe disposal of these pollutants are of primary concern due to their toxic and long term effects on humans and animals (Meena et al., 2015). Partially treated

Revised Manuscript Received on December 15, 2019.

* Correspondence Author

Naresh K. Sharma, Biotechnology, Kalasalingam Academy of Research and Education, Tamilnadu, INDIA. Email: naresh@klu.ac.in

Berlin M.*, Department of Civil Engineering, National Institute of Technology Arunachal Pradesh, INDIA. Email: berlin@nitap.ac.in or untreated phenolic wastewater when discharged into soil or subsoil surface culminates in accumulation of these compounds which may affect the groundwater quality. Due to volatility few of the phenolic compounds are also released into the atmosphere through industrial and vehicular activities and eventually reach water bodies. Phenolic compounds have been proven to cause various diseases and inebrieties in both animals and humans either through skin absorption or intake from contaminated groundwater (Meena et al., 2015). In spite of several advanced phenol removal techniques (such as membrane-based separation method, electro-Fenton method, biodegradation, photo catalysis and so on), industrial wastewater treatment in many developing countries does not follow regulatory standards and wastewater are discharged untreated or in many cases partially treated (Kahru et al, 2002). Water resources can be restored by careful application of domestic or industrial wastewater for irrigation; this prevents contamination of surface water sources and mitigates water scarcity. In the past two decades, wastewater has been applied for irrigation of several crops and has become a common practice in several developing countries, adversely the applied wastewater if consists of toxic compounds could affect the groundwater quality and cause several food and water borne diseases, especially if the wastewater is not treated to standards, it contains, organic pollutants, inorganic chemicals and acclimated microbes from the secondary treatment units (Haruvy, 2006). Comparatively, modeling studies which includes the biodegradation process of phenolic pollutants along with its transport in an unsaturated porous media are few, here an attempt is made to develop a numerical model based on Haldane's inhibition kinetics and Richard's transport equation to predict the fate and transport of phenol when discharged on a soil media from a partially treated industrial wastewater discharge.

\section{MODEL DESCRIPTION}

In this study, a one-dimensional model is proposed which incorporates for the following phenomena: water flow, phenol and cresol transport along with the biodegradation.

\section{A. Water flow modeling}

Richard's equation is commonly used for one-dimensional downward movement of water in the unsaturated zone of soil with water uptake by plant roots (Antonopoulos, 2006):

$$
C(h) \frac{\partial h}{\partial t}=\frac{\partial}{\partial z} K\left(\frac{\partial h}{\partial z}\right)-\frac{\partial K}{\partial z}+S_{W}
$$


Where: $C(h)=\frac{\partial \theta}{\partial h}$ is specific moisture capacity $(1 / \mathrm{L}) ; \mathrm{h}$ is the pressure head (L); $\mathrm{K}$ is the hydraulic conductivity of unsaturated soil (L/T); $S_{w}$ is the water abstraction by plant $\left(\mathrm{L}^{3}\right.$ $\left.\mathrm{L}^{-3} \mathrm{~T}^{-1}\right) ; t$ is the time (T); $z$ is the downward depth $(\mathrm{L})$.

In the present study, the hydraulic conductivity and the hydraulic soil functions of water retention are used as follows:

$$
\begin{aligned}
& S_{e}=\frac{\theta_{w}-\theta_{r}}{\theta_{s}-\theta_{r}} \\
& \theta_{w}=\theta_{r}+\frac{\theta_{s}-\theta_{r}}{\left.(1+\mid \alpha h]^{\beta}\right)^{\eta}} \\
& K(h)=K_{s} S_{e}^{1 / 2}\left[1-\left(1-S_{e}^{1 / \eta}\right)^{\eta}\right]^{2}
\end{aligned}
$$

where: $\theta_{w}$ is the water content $\left(\mathrm{L}^{3} / \mathrm{L}^{3}\right) ; \theta_{s}$ is the saturated water content; $\theta_{r}$ is the residual water content; $K_{s}$ is the saturated hydraulic conductivity $(\mathrm{L} / \mathrm{T}) ; S_{e}$ is the effective saturation; $\alpha, \beta$ and $\eta$ are fitting parameters.

\section{B. Phenol transport and biodegradation}

The one-dimensional transport of phenol in under saturated soil conditions are described by the equation 5 :

$R \frac{\partial \theta C}{\partial t}=\frac{\partial}{\partial z}\left(\theta D \frac{\partial C}{\partial z}\right)-\frac{\partial q C}{\partial z}-\phi_{1}$

where $C$ is the concentration of phenol/cresol; $D=D_{0} * \tau+q * \lambda_{L}$, $D_{0}$ is the molecular diffusion coefficient; $q$ is the Darcy velocity; $\lambda_{L}$ is the longitudinal dispersivity; $\tau$ is the tortuasity; $\rho$ is the bulk density; $D$ is the dispersion coefficient; $\Phi_{l}$ is the biodegradation rate of phenol/cresol per unit soil volume; $\mathrm{R}$ is the retardation factor for phenol/cresol based on the linear partitioning coefficient $\left(R=1+\frac{\rho_{b} N_{d \bar{d}}}{\theta_{v e}}\right) ; \rho_{\mathrm{b}}$ is the bulk density of soil; $\mathrm{K}_{\mathrm{d}}$ is the linear partitioning coefficient.

The biodegradation term $\Phi_{1}$ describe the kinetic behavior of phenol/cresol which is described by Haldane model shown in equations 6 and 7 .

$\phi_{1}=\frac{d C}{d t}=\frac{M}{Y_{P}} \frac{\mathscr{M}_{\max } C}{K_{C}+C+\frac{C^{2}}{\mathbb{K}_{i}}}$

$\frac{d M}{d t}=M \frac{\mathbb{M}_{\max } C}{\mathbb{R}_{c}+C+\frac{C^{2}}{\mathbb{R}_{\text {it }}}}$

where $M$ is the bacterial concentration, $\mu_{\max }$ is the maximum specific growth rate, $\mathrm{Y}_{\mathrm{T}}$ is the yield coefficient, $\mathrm{K}_{\mathrm{c}}$ is the half saturation constant, $\mathrm{K}_{\mathrm{i}}$ is the inhibition constant.

The water flow equation (1) and phenol transport equations (5) and (6) pertains the following initial and boundary conditions:

$h(z, t=0)=h_{i}, C(z, t=0)=C_{i}$

$h(z=0, t)=h_{1}$ and $h(z=L, t)=h_{2}$
$C(z=0, t)=C_{l}$ and $\partial \mathrm{C} / \partial \mathrm{z}(z=L, t)=0$

where $h_{l}$ and $C_{l}$ are the surface boundary condition of the pressure head and phenol/cresol concentrations, respectively, $h_{i}$ and $C_{i}$ are the initial distribution of the pressure head and phenol/cresol concentrations, respectively. $h_{2}$ is the pressure head at the bottom of the domain, $L$ is the total depth of unsaturated zone.

\section{NUMERICAL SOLUTION}

The partial differential equations (1), (5), (6) and (7) pertaining water movement and contaminant migration model, with their initial and boundary conditions Eqs. (8) (10), are solved by the finite difference scheme. The prevalent technique to solve Eq. (1) has been the implicit finite difference scheme with explicit linearization of $\mathrm{K}(\mathrm{h})$ and $\mathrm{C}(\mathrm{h})$ (van Dam and Feddes, 2000). The phenol/cresol model represented by Eqs. (5) - (7) are solved by fully implicit finite difference method. Thomas algorithm is employed to resolve the subsequent tri-diagonal system of linear algebraic equations. The pressure head values in the unsaturated soil profile are obtained by unsaturated flow model. The acquired values of pressure head $h(z, t)$ are used to find $q(z, t), \theta(z, t)$, and $D(z, t)$ which available in the transport equation of phenol. Later, the phenol migration model is solved for assumed initial and boundary condition. The base values of the parameters used in the study for transport process is given in Table.1 while the biodegradation kinetics for phenol metabolism for a mixed microbial consortia is given in Table 2 (Sharma et al., 2012).

\section{RESULTS AND DISCUSSION}

Phenol transport and biodegradation in under saturated porous media has been predicted successfully by the developed numerical model. The numerical result of present water flow model in vadoze zone is endorsed with the existing reported analytical/numerical results. From Fig. 1, it is observed that the current model outcomes are in good agreement match with the available results (Mitchell and Mayer, 1998). The effect of microbial concentration on phenol removal is revealed in Fig. 2.

It is noted that with $0.1 \mathrm{mg} / \mathrm{L}$ of initial microbial concentration, phenol is completed removed at a soil depth of $40 \mathrm{~cm}$ from initial phenol concentration of $1500 \mathrm{mg} / \mathrm{L}$. However, with $0.001 \mathrm{mg} / \mathrm{L}$ of initial microbial concentration, complete removal is observed at $160 \mathrm{~cm}$ of soil depth. The phenol biodegradation kinetics for the acclimated culture here has relatively better growth rate and half saturation constant

\begin{tabular}{|c|c|c|c|}
\hline Parameter & Symbol & Value & Reference \\
\hline $\begin{array}{l}\text { Depth of } \\
\text { unsaturated } \\
\text { zone }\end{array}$ & -- & $500 \mathrm{~cm}$ & Assumed \\
\hline $\begin{array}{l}\text { Simulation } \\
\text { time }\end{array}$ & -- & 5 hours & Assumed \\
\hline $\begin{array}{l}\text { Van } \\
\text { Genuchten } \\
\text { parameter }\end{array}$ & $\alpha$ & $\begin{array}{l}0.0335 \\
\left(\mathrm{~cm}^{-1}\right)\end{array}$ & $\begin{array}{l}\text { Mitchell \& } \\
\text { Mayer (1998) }\end{array}$ \\
\hline $\begin{array}{l}\text { Publish } \\
\text { Blue E. } \\
\text { \& Scier }\end{array}$ & $\begin{array}{l}\text { : } \\
\text { telligence } \\
\text { ublicatior }\end{array}$ & gineering & \\
\hline
\end{tabular}
as is was already acclimated with phenolic compounds.

Table 1. Base values of parameters used in this study 


\begin{tabular}{|c|c|c|c|}
\hline $\begin{array}{l}\text { Van } \\
\text { Genuchten } \\
\text { parameter }\end{array}$ & $\beta$ & 2.0 & $\begin{array}{l}\text { Mitchell \& } \\
\text { Mayer (1998) }\end{array}$ \\
\hline $\begin{array}{l}\text { Van } \\
\text { Genuchten } \\
\text { parameter }\end{array}$ & $\eta$ & 0.5 & $\begin{array}{l}\text { Mitchell \& } \\
\text { Mayer (1998) }\end{array}$ \\
\hline $\begin{array}{l}\text { Saturated } \\
\text { water content }\end{array}$ & $\theta_{g}$ & $\begin{array}{l}0.381 \\
\left(\mathrm{~cm}^{3} / \mathrm{cm}^{3}\right)\end{array}$ & $\begin{array}{l}\text { Mitchell \& } \\
\text { Mayer (1998) }\end{array}$ \\
\hline $\begin{array}{l}\text { Residual water } \\
\text { content }\end{array}$ & $\theta_{Y}$ & $\begin{array}{l}0.102 \\
\left(\mathrm{~cm}^{3} / \mathrm{cm}^{3}\right)\end{array}$ & $\begin{array}{l}\text { Mitchell \& } \\
\text { Mayer (1998) }\end{array}$ \\
\hline $\begin{array}{l}\text { Saturated } \\
\text { hydraulic } \\
\text { conductivity }\end{array}$ & $K_{g}$ & $\begin{array}{l}0.00922 \\
\mathrm{~cm} / \mathrm{s}\end{array}$ & $\begin{array}{l}\text { Mitchell \& } \\
\text { Mayer (1998) }\end{array}$ \\
\hline $\begin{array}{l}\text { Soil bulk } \\
\text { density }\end{array}$ & $\rho_{\mathrm{b}}$ & $\begin{array}{l}1.56 \times 10^{6} \\
\mathrm{mg} / \mathrm{l}\end{array}$ & $\begin{array}{l}\text { Lee et al., } \\
(2006)\end{array}$ \\
\hline $\begin{array}{l}\text { Molecular } \\
\text { diffusion } \\
\text { coefficient }\end{array}$ & $D_{0}$ & $0.12 \mathrm{~cm}^{2} / \mathrm{h}$ & \begin{tabular}{l}
\multicolumn{2}{l}{ Kaluarachchi } \\
$\begin{array}{ll}\text { \& } & \text { Parker } \\
(1988) & \end{array}$
\end{tabular} \\
\hline Tortuasity & $\tau$ & 1 & Assumed \\
\hline $\begin{array}{l}\text { Longitudinal } \\
\text { dispersivity }\end{array}$ & $\lambda_{L}$ & $0.5 \mathrm{~cm}$ & $\begin{array}{l}\text { Lee et al., } \\
(2006)\end{array}$ \\
\hline $\begin{array}{l}\text { Distribution } \\
\text { coefficient }\end{array}$ & $\mathrm{k}_{\mathrm{d}}$ & $\begin{array}{l}3 \times 10^{-8} \text { to } \\
8 \times 10^{-8} \mathrm{l} / \mathrm{mg}\end{array}$ & $\begin{array}{l}\text { Viotti et al., } \\
(2005)\end{array}$ \\
\hline
\end{tabular}

Table 2: Bio-kinetic constants for Haldane model (Sharma et al., 2012)

\begin{tabular}{|l|l|l|}
\hline Parameter & Symbol & Phenol \\
\hline $\begin{array}{l}\text { Maximum growth rate } \\
(1 / \mathrm{h})\end{array}$ & $\mu_{\max }$ & 0.13 \\
\hline $\begin{array}{l}\text { Half saturation constant } \\
(\mathrm{mg} / \mathrm{L})\end{array}$ & $\mathrm{K}_{\mathrm{c}}$ & 29.1 \\
\hline $\begin{array}{l}\text { Yield coefficient } \\
(\mathrm{mg} / \mathrm{mg})\end{array}$ & $\mathrm{Y}_{\mathrm{T}}$ & 0.31 \\
\hline $\begin{array}{l}\text { Inhibition } \\
\text { concentration }(\mathrm{mg} / \mathrm{L})\end{array}$ & $\mathrm{K}_{\mathrm{i}}$ & 432.2 \\
\hline
\end{tabular}

As the microbial concentration increases so does the biodegradation of phenol, this effect could be observed as both the 0.01 and $0.001 \mathrm{mg} / \mathrm{L}$ of initial microbial concentration reaches undetectable levels of phenol at the depth of $160 \mathrm{~cm}$. Fig 3 shows the vertical transport of phenol at different time interval along with the adsorption and biodegradation process. The results show that the concentration becomes undetectable at the depth of $100 \mathrm{~cm}$ and $180 \mathrm{~cm}$ after $5^{\text {th }}$ and $10^{\text {th }}$ day respectively. On the other hand, the concentration become nearly zero at the depth of approximately $80 \mathrm{~cm}$ and again increase to $350 \mathrm{mg} / \mathrm{l}$ at the depth of nearly $140 \mathrm{~cm}$ and reaches zero at the depth of 200 $\mathrm{cm}$ at $12^{\text {th }}$ day. This initial decrease is due to the high consumption of phenol by the bacteria in the shallow depths and the same has been shown in Fig 4. However, the increase in concentration observed between the depths of $80 \mathrm{~cm}$ to 200 $\mathrm{cm}$ is due to the advection and dispersion phenomena. Hence, it can be concluded that the physical processes such as advection and dispersion may be predominant in the initial time and later the biodegradation become more predominate. Similarly, the $13^{\text {th }}$ day concentration profile is also follows the previous day trend with more reduction. This is due to the further concentration increase in bacteria in the shallow depths (Fig 4). The adsorption and desorption potential of phenol is reflected in Fig. 3.

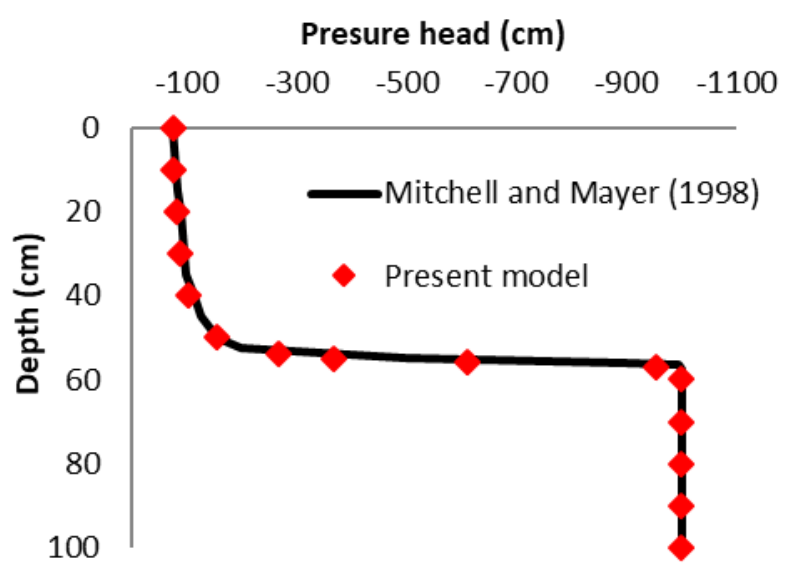

Fig 1: Validation of the present model for flow in unsaturated soil after 1 day

Phenol Concentration (mg/l)

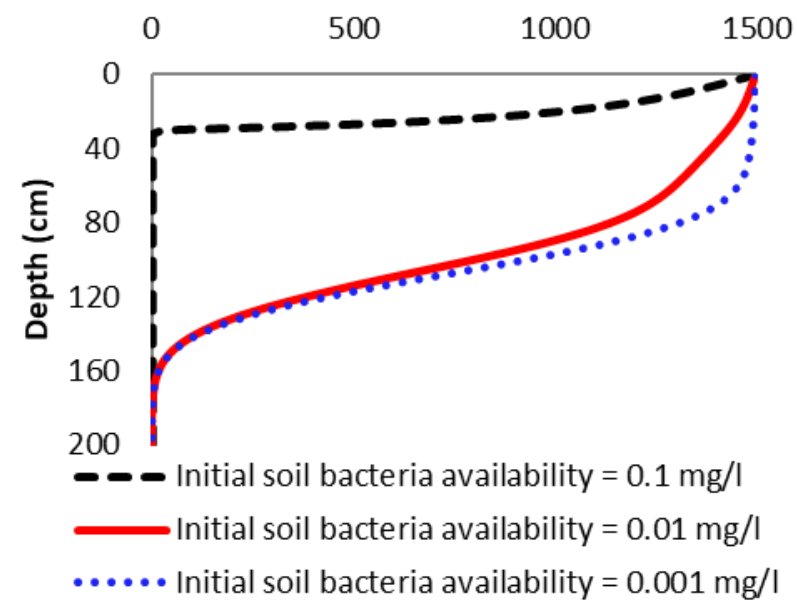

Fig.2: Concentration profile for phenol in the presence during the variation in initial soil bacteria concentration (refer to Tables 1 and 2 for other data)

Up to $10^{\text {th }}$ day, phenol is completely utilized by the microbes and no adsorption of the pollutants to soil media is observed. At a depth of $200 \mathrm{~cm}$ and 10 days of phenol wastewater discharge $(1500 \mathrm{mg} / \mathrm{L})$, biodegradation is the primary process for phenol removal. However, after $12 \mathrm{~d}$ of phenol application to the soil, much of the phenol adsorbs to the soil media along noticeable biodegradation removal. However, at the depth of $100 \mathrm{~cm}$, phenol is dispersed from the soil surface and is available for bacterial degradation, which quickly occurs and A similar pattern could be observed on $13^{\text {th }}$ day where there is desorption of phenol molecules and gradual biodegradation, till reaches a depth of $200 \mathrm{~cm}$. With continuous phenol discharge at initial concentration of $1500 \mathrm{mg} / \mathrm{L}$, both adsorption and biodegradation process significantly remove phenol in the soil media. A considerable increase in microbial concentration could be seen at 10,12 and 13 days upto 800 $\mathrm{mg} / \mathrm{L}$ from initial microbial concentration of $0.01 \mathrm{mg} / \mathrm{L}$ (Fig. 4). Since the microbes have already been acclimated to phenolic compounds, the mixed consortia dominated by Pseudomonas and Bacillus sp, 
could easily metabolize phenol as primary carbon source and therefore increased biomass concentration.

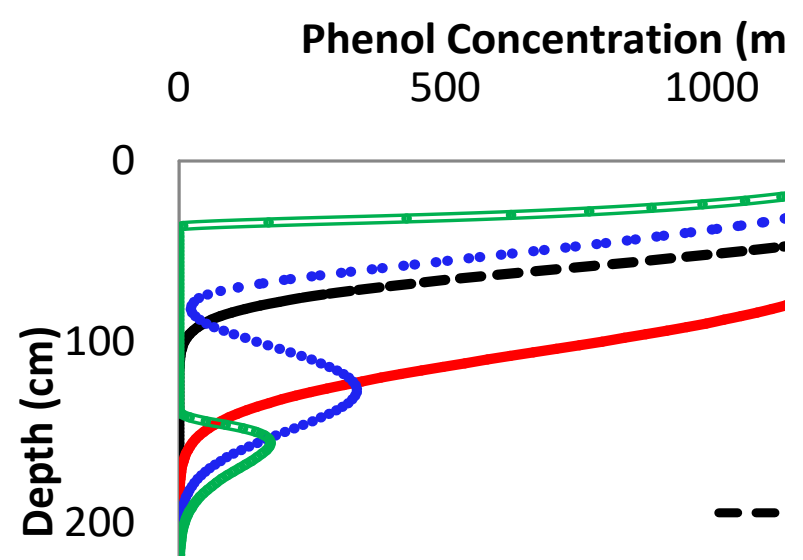

Fig.3: Concentration profile for phenol at different time with the initial soil bacterial concentration of $0.01 \mathrm{mg} / \mathrm{l}$ (refer to Tables 1 and 2 for other data)

\section{Bacteria Concentration ( $r$ 0 500}

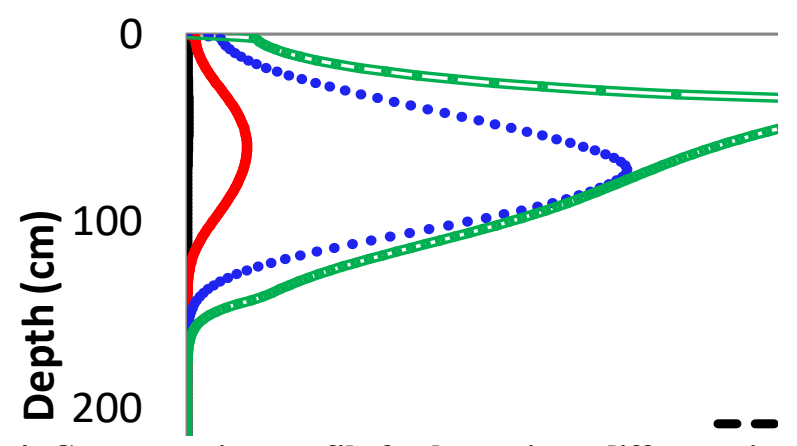

Fig.4: Concentration profile for bacteria at different time with the initial soil bacterial concentration of $0.01 \mathrm{mg} / \mathrm{l}$ (refer to Tables 1 and 2 for other data)

\section{CONCLUSION}

In this study, a numerical model is developed which describes the transport, adsorption and transformation of phenol in presence of acclimated biomass using Haldane inhibition model. With continuous phenol discharge (initial concentration $1500 \mathrm{mg} / \mathrm{L}$ ) from partially treated wastewater containing acclimated microbes $(0.1 \mathrm{mg} / \mathrm{L}$ initial biomass concentration), it could be seen that with phenols are undetected at a depth of $40 \mathrm{~cm}$. Also, advection and dispersion of phenol on soil media was noticed with very heavy phenol discharge by 12 and $13^{\text {th }}$ day of application. However, due to increased biomass, the desorbed phenol could be utilized by the microbes by the depth of $200 \mathrm{~cm}$.

\section{ACKNOWLEDGMENT}

The authors feel thankful to the support offered by Prof. Ligy Philip, Prof. B S Murty, Prof. Indumati M Nambi, Department of Civil Engineering and Prof. G. Suresh Kumar, Department of Ocean Engineering, IIT Madras for the fruition of this study.

\section{REFERENCES}

[1] Agency for Toxic Substances and Disease Registry (2008). Toxicological profile for phenol, U.S. department of health and human services, public health service, 200-269

[2] Meena, M. C., Rahul Band \& Girish Sharma (2015). Phenol and its toxicity: A case study. Iranian Journal of Toxicology, 8 (27), 1221-1225.

[3] Kahru, A., Alla Maloverjan, Helgi Sillak, Lee Põllumaa (2002), The toxicity and fate of phenolic pollutants in the contaminated soils associated with the oil-shale industry, Environmental Science and Pollution Research, 9(1), 27-33.

[4] Haruvy, N (2006), Environmental Security and Environmental Management: The Role of Risk Assessment, 5, 257-262.

[5] Antonopoulos V Z 2006 Water movement and heat transfer simulations in a soil under ryegrass. Biosyst. Eng. 95(1): 127-138

[6] Sharma N K, Ligy P and Murty B S., (2012). Aerobic Aerobic degradation of phenolics and aromatic hydrocarbons in presence of cyanide. Bioresource Technology 121, 263-273.

[7] Mitchell, R. J., \& Mayer, A. S. (1998). A numerical model for transient-hysteretic flow and solution transport in unsaturated porous media. Journal of Contaminant Hydrology, 50, 243-264.

[8] Lee, M. S., Lee, K. K., Hyun, Y., Clement, T. P., \& Hamilton, D. (2006). Nitrogen transformation and transport modeling in groundwater aquifers. Ecological Modeling, 192, 143-159.

[9] Kaluarachchi, J., \& Parker, J. C. (1988). Finite element model of nitrogen species transformation and transport in the unsaturated zone. Journal of Hydrology, 109, 249-274.

[10] Viotti P., Petrangeli Papini M., Stracqualursi N., Gamba C., Contaminant transport in an unsaturated soil: laboratory tests and numerical simulation model as procedure for parameters evaluation. Ecological Modelling 182 (2005) 131-148

\section{AUTHORS PROFILE}

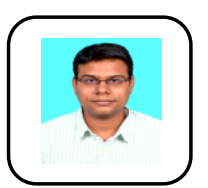

Naresh Kumar Sharma is an Associate Professor at Kalasalingam University in Department of Biotechnology. He completed his PhD from IIT Madras. His research interests include bioremediation and wastewater treatment

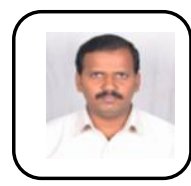

Berlin $\mathbf{M}$ is an Assistant Professor, Department of Civil Engineering at National Institute of Technology Arunachal Pradesh. He completed his $\mathrm{PhD}$ from IIT Madras and his research interests includes contaminant transport modeling in porous media. 